\title{
JOHN STUART MILL, VICTORIAN LIBERALISM, AND THE FAILURE OF
}

\section{COOPERATIVE PRODUCTION*}

\author{
JOCELYN PAUL BETTS
}

Corpus Christi College, University of Cambridge

Mill and Cooperative Production

John Stuart Mill's support for, and predictions of, cooperative production have been taken as a coherent wedding of liberal and socialist concerns, and as drawing together later nineteenth-century political economy and working-class radicalism. Despite its evident significance, the alliance of political economy and cooperative production was, however, highly conflicted, contested, and short-lived, in ways that help to shed light on the construction of knowledge of society in nineteenth-century Britain. Mill's vision should be seen as developed in contrast to the sociological and historical perspectives of Auguste Comte and Thomas Carlyle, as an attempt to hold together political economy as a valid form of knowledge with the hope of a new social stage in which commerce would be imbued with public spirit. This ideal thus involved debate about competing social futures and the tools of prediction, as well as entering debates within political economy where it was equally embattled. Even Mill's own economic logic tended more towards support of profit-sharing than cooperative production, and hopes for the latter became significantly less persuasive with the introduction of the concept of the entrepreneur into mainstream British economics during the 1870s and 1880s.

John Stuart Mill's Principles of political economy with some of their applications to social philosophy, published in seven editions between 1848 and 1871, was the dominant text in economic thought at the high point of Victorian liberalism. There was one chapter of this work that Mill thought had 'a greater influence on opinion than all the rest': chapter seven of book four, or 'On the probable futurity of the labouring classes'. ${ }^{1}$ This was the chapter in which Mill outlined his support for, and predictions of, the end of wage labour and its replacement by profit-sharing and cooperative production. On the publication of the Principles the chapter helped to win over the allegiance of working-class cooperators and Christian Socialists to Mill's restatement of Ricardian economics. ${ }^{2}$ The chapter became an important reference point for Mill's allies among political economists, including John 
Elliott Cairnes, Henry Fawcett, and William Thomas Thornton, as well as a young Alfred Marshall. ${ }^{3}$ The significance of the chapter was still evident in 1892 when the economist Langford Lovell Price informed readers of the Economic Journal that wage labour was generally viewed as a temporary phenomenon and that the 'plain, average man' if asked about the future of the economy, would respond with the words of the 'Probable futurity' that predicted a transition through associations of labourers with capitalists, to associations of labourers among themselves. ${ }^{4}$ The potential force of this belief is shown by Beatrice Webb's recollection of Odgers, secretary of the Cooperative Insurance Company in 1889, who had been inspired by the 'Probable futurity' to give up a salary of two hundred pounds a year in order to become a cooperative employee earning one pound a week. ${ }^{5}$

The chapter has understandably been cited as an important aspect of Mill's establishing of a 'two-way relationship between 'official' and popular economic culture', helping to make cooperators Liberals and to make liberals sympathetic to cooperation, so that 'during the second half of the century no ideological barrier had been left between Liberalism and co-operativism'. ${ }^{6}$ This interpretation of Victorian liberalism can be seen to fit neatly with prevalent interpretations of Mill's cooperation. ${ }^{7}$ Whilst this literature is large and varied, it has displayed a strong recent tendency to stress Mill's theoretical coherence in the marrying of his liberal ideals of individual independence with his concern to alter distribution, and specifically to end capitalist control of businesses. ${ }^{8}$ Showing the way in which Mill's liberal values could lead directly to his cooperative commitments lends an evident credence to the possibility of a broader merging of orthodox political economy and the hopes of certain working-class radicals.

If Mill's predictions of cooperative production had a kind of moral coherence, and an undeniably broad impact, they were also, however, a difficult marriage of social science and political economy, and ultimately a failure. They were a failure not only in the 
sense that wage labour persisted, but also in the more important sense that the mainstream of economic thought quite clearly came by the 1890s to regard the possibility of worker ownership and control of businesses as implausible, a conclusion that can be seen as incipient already in earlier opposition to Mill's views and in his own vacillations as to the practicability of abolishing the capitalist in the 1860s. The alliance of a critique of capitalist profit and control with political economy depended on a mid-Victorian ambiguity surrounding the theorization of business leadership: the conflation of ideas of organizational skill and authority with investment in the language of the 'capitalist', later fatally eroded by the arrival of the 'entrepreneur'.

Understanding these facts aright helps to temper ideas of the closeness of the relationship between liberalism and cooperation, and shows a sense in which 'official' economic culture never fully accommodated working-class radicalism. It also sheds light on the thinking of Mill, helping to show the conceptual fragility of predicting a new form of sociability that would go beyond mere exchange emerging from the workings of a competitive market with their ultimate requirements of efficiency. Discussion of Mill's ideals on a range of issues of economic reform has now been highly developed. ${ }^{9}$ What has not been captured, however, is the broader story of Mill's failure to fully integrate cooperation into political economy, which has potential implications for how one understands the balance of his normative aims and their possible tensions. More generally, Mill's liberal vision of a classless society was thus an important episode in the history of the relationship between political and social thought and the authority of economics. Its failure when situated in a broad context becomes in one sense a failure of liberalism to reconcile economic analysis with the ideal of fully extinguishing hierarchies of status within civil society. 
That Mill's primary moral aims were not necessarily tied to the abolition of the capitalist, and that his argumentative contexts were torn between economic and more historical forms of knowledge, is aided by first acknowledging that in an important and neglected sense Mill's predictions of cooperation emerged from his negotiation with the ideas of his interlocutors Thomas Carlyle and Auguste Comte. This negotiation was to help to shape a long pattern of nineteenth-century argument. It was natural for Mill to think of these figures as a pair. Mill recalled his first encounters with the ideas of Comte, the Saint-Simonians, and Carlyle in the late 1820s and early 1830s together in his Autobiography; they had helped to cement Mill's sense of living through a period of transition on the way to a new permanent moral epoch in which creeds would no longer 'require to be periodically thrown off. ${ }^{10}$ Mill was thereafter inclined to view the period from the Catholic Relief Act of 1829 to the electoral reforms of 1832 (the period also of the July Revolution of 1830 in France) as having inculcated among the populace at large the same profound sense of living in a world of change, in a way that brought the possibility of resolving class conflict to the fore. ${ }^{11}$ The common ground between Mill, the Saint-Simonians, Comte, and Carlyle was not simply a general sense of orientation to the future. ${ }^{12}$ It also involved a shared desire to see a resolution to class conflict and an end to the corrosive effects of commerce on public morality.

This common context was still pressing for Mill in the early 1840s, when he was in correspondence with Comte, and Carlyle had entered a new phase of his career as a social critic with his pamphlet on Chartism. ${ }^{13}$ Late in 1842, after finishing the last volume of Comte's Cours de philosophie positive, Mill wrote to Comte of the 'great and luminous new idea' Comte had outlined, that 'high social qualities' were to be discovered in 'the world of business and industry, notwithstanding the essentially egotistical motives that today rule almost exclusively.' He was reminded of recent conversations with Carlyle, who had insisted that it would be possible to find a 'poetic idealization' of industry, given that 
military life had been similarly lauded despite the inherent repulsiveness of its violence. Comte had convinced Mill that the sociability found in armies was due to the function that they performed, providing intellectual and moral discipline to groups of men associating for a common end. A 'true organization of industry' would serve the same purpose, and Mill wrote that he was now able to abandon the fears he had experienced as to the decline of sociability in an 'epoch of transition' and a 'modern kind of industrial civilization'. ${ }^{14}$ These were fears Mill had most eloquently expressed in his essay 'Civilization' in $1836 .{ }^{15}$ Mill had extracted Comte's tonic, strikingly, from a strident statement of the need to abolish the distinction between private and public functions. ${ }^{16}$ Mill never lost his appreciation for this military metaphor for industrial sociability, and it was reiterated in Auguste Comte and positivism in $1865 .{ }^{17}$ Carlyle's similar reflections germinated in early 1843 in Past and present's emphases on noble and competent 'Captains of Industry' and the replacement of 'Arms and the Man' by 'Tools and the Man' as a new epic theme. ${ }^{18}$ Whilst for both Carlyle and Comte such language represented a level of commitment to social hierarchy Mill did not share, its basic common purpose was to stress the possibility of subordinating economic life to public interests, to the 'interest in the common good' Mill would come to see cooperative societies as representing. ${ }^{19}$ The uneasy shared usage of this imagery of public service was to continue to play out, with Carlyle's sense reiterated by Ruskin alongside his virulent opposition to Mill's economics from the 1860 s onwards. ${ }^{20}$

Mill's 'Probable futurity' was in one sense a kindred text with Comte's own predictions and Carlyle's Past and present, all three concerned to forecast the way in which economic life was tending towards a reformation that would provide a new kind of social cohesion buttressing social and political order. Yet the idea of giving the private realm of commerce a new public spirit operated very differently for Mill than for either Comte or Carlyle. Comte shared with the Saint-Simonians a historical sense based on the imminent 
end of a critical period and the emergence of a new organic unity, which would involve a spiritual power of scientists directing and morally overseeing a temporal power based on existing economic hierarchies and devoted to peaceful material advancement, or industrialism, that would end the disastrous militarism of the Revolutionary and Napoleonic wars. ${ }^{21}$ This was a contribution to understanding how to close the periodic constitutional crises set in train by the French Revolution. ${ }^{22}$ Yet despite Saint-Simon having shared a sense of the importance of industry with more obviously liberal figures such as Jean-Baptiste Say, both he and Comte became increasingly hostile to using political economy as a foundation for a scientific understanding of society. ${ }^{23}$ For Comte political economy after Adam Smith relied too much on a thin logic devoid of observation, and in its conclusions helped to buttress the social atomism of the eighteenth century that logically tended to deny the significance of government. ${ }^{24}$ Political economy was ultimately a threat to a united science of society and politics. ${ }^{25}$ The 'organization of industry' and the end of private commercial interests was for Comte to be understood as part of a moral and intellectual shift of epochs, outlined by a sociology that required no science of the workings of civil society separate from forms of administration. Despite evident differences, there were also strong parallels here with the ideas of Carlyle. Beyond Carlyle's sense of the rising importance of industry and its replacement of militarism, he too saw the French Revolution as the culmination of a negative period of atomism and hollowed-out authority, with political economy's worship of wealth and doctrine of laissez-faire part of the general crisis. Likewise, he tended to collapse distinctions between society and government, regarding the instating of right authority as a question of a general historical transition in morality and ideas, operating across economic life and politics. Mill was keen, by contrast, to preserve the authority of political economy. This went hand in hand with seeing virtue as hinging on an active character that could be fostered by competition, and regarding the 'organization 
of industry' as the incorporation of commerce into an associational world that was oriented to the public good, but which would still counterbalance the state. ${ }^{26}$

Mill's journey towards the 'Probable futurity' was thus also one of differentiating his conception of the future economy from both Carlyle and Comte, and the two texts that were the clearest precursors of the 'Probable futurity' were directed against them. The first was a review of Arthur Helps' Claims of labour in 1845. Mill had been perturbed by tendencies to discuss questions of poverty and class conflict with decreasing reference to the lessons of political economy. In the wake of Chartist disturbances, and increasing interest in working-class life drawing on the reports of various Royal Commissions, Mill saw a fashionable movement towards an ill-informed philanthropy. The statements of the Young England group around Disraeli, the social thinking of the Tractarians, and the impact of the writings of Carlyle, who Helps overtly admired, were all helping to speed the current. ${ }^{27}$ Mill saw a need to recall the public's attention to the lessons of Malthus, that a true solution to poverty required the fostering of responsibility for family size. More fundamentally, Mill argued that any attempt to benevolently raise the condition of workers without concern for their own self-regulation would lead to control of all aspects of their lives. Such a proposition was not only undesirable but impractical given the progress of the 'spirit of equality and the love of individual independence'. ${ }^{28}$ This was a direct precursor of the first section of the 'Probable futurity' which sought to show the way that theorists of 'dependence', advocating a benevolent hierarchy to solve social problems, were out of joint with the times. ${ }^{29}$

Mill's concerns over British public debate and policy on poverty continued throughout the 1840s, and during the course of the Irish famine between 1846 and 1847, as he was composing the Principles, he was driven to distraction by what he saw as the lack of sufficiently serious long-term thinking about how to solve the situation. ${ }^{30}$ In May of 1847, six months after Comte had last written to Mill requesting a further arrangement 
of the financial support Mill had helped with previously, Mill wrote his final response. It was a kind of ironic commentary on Comte's ideas, describing the famine as a period of crisis aggravated by philanthropic intentions, which would lead through 'total chaos' and a 'more or less anarchic way of life' towards the need for a 'reconstruction of society', parodying the way that Comte had united political economy and the selfishness it stood for with the atomistic crisis of the eighteenth century that would lead towards a new Positivist order. Mill's crowning statement was that to treat workers as 'cattle', asking them to work for 'good food and housing' was only possible 'when the whip was added', and that thus 'In industry as elsewhere, we cannot make the old system work while stripping it, one by one, of its means of action. ${ }^{31}$ The closeness of this sentiment to those of the 'Probable futurity' helps to confirm that Comte stood amongst those Mill sought to criticize. ${ }^{32}$ For Mill the visions of both Comte and Carlyle were plausibly reducible to the addition of benevolent authority to existing hierarchical structures. Though both Carlyle and Comte were capable of an appreciation of Malthus, in Mill's eyes they did not safeguard the motivational power of competition, needed not only to avert Malthusisan catastrophe but also the enervation of active character. ${ }^{33}$

Seen in this light there is a difficulty with reading the 'Probable futurity' at face value as an attack on those who wanted to return to some imagined past or defend the social status quo. ${ }^{34}$ Mill was also engaging in a quite different form of debate, based on competing predictions and their sanction from historical interpretation. ${ }^{35}$ This was made explicit by Mill in 1865. Comte's predictions left 'positive thinkers on the one hand, leaders of industry on the other, the future necessarily belongs to these: spiritual power to the former, temporal to the latter. As a specimen of historical forecast this is very deficient; for are there not the masses as well as the leaders of industry? and is not theirs also a growing power? ${ }^{36}$ Comte had not extrapolated from existing tendencies at work through the whole of history in the manner of Tocqueville, who for Mill had 
convincingly discussed the inevitable coming of social equality based on an understanding of the whole course of civilization. ${ }^{37}$ Tocqueville did, however, stand as backing for Mill's own method in the 'Probable futurity', which built a narrative out of the Reformation, the rise of political agitation, the circulation of newspapers, and growing worker mobility, to suggest that demands for equality of status were irreversible. ${ }^{38}$ In mobilizing Tocqueville as the model for a linear view of the course of history to counteract the cyclical return of socially appropriate forms of authority, Mill was making a defensive move. The writings of Comte and Carlyle implied that Mill's social liberalism and political economy were archaic relics of the eighteenth century. Mill was not putting an inherently progressive point of view, but having to argue about what progress consisted of, and to do so through negotiation over method in social science, and the nature of the moral and mental developments that it revealed. The immediate importance of the social ideals of the Oxford Movement, Young England, and also Carlyle were to noticeably wane from the late 1840s onwards as their publications slowed and the 'Condition-of-England question' came to appear less politically and economically pressing. Yet both Carlyle and Comte as well as Mill contributed markedly to a growing Victorian sense of economic life as moving towards a more socially cohesive future rather than representing a completely fixed order, and the idea of moralized economic leadership was to continue to compete with Mill's vision of a coming era of equal status.

III

At one level Mill's narrative of workers' growing desires for independence lent support to the idea of the end of hiring and service, as workers would seek to throw off the shackles of wage labour. ${ }^{39}$ This desire would become even more pronounced as the approach of the stationary state and the slowing of economic growth weakened workers' individual prospects of advance to self-employment. ${ }^{40}$ Yet this line of thinking remained primarily a 
negative argument refuting alternative futures. It held no force as a prediction of new forms of economic organization, which instead required an account of the competitive disadvantages of wage labour. Thus whilst the 'Probable futurity' was engaged in questions of historical development, its predictive authority involved reasoning about wages, profits, and the nature of the firm that lay squarely within the relatively temporally static conceptual world of political economy, and this represented a very different argumentative context, and a weak point of Millian backing for cooperative production.

Mill saw the competitiveness of different types of economic organization as determined largely by the motivation that they induced in their members. Giving hired employees a share of profits increased their motivation and productivity and made firms more competitive. This principle worked in favour of both profit-sharing and cooperative production. Yet there was a countervailing influence in the motivation that an individual owner gained from his much greater pecuniary interest in the overall success and failure of a business, which maximized his zeal in management. On this account, profit-sharing had one advantage that cooperative production did not. Jointstock companies, by contrast, potentially suffered from both being run by a hired manager, and also not having a highly motivated workforce, helping to explain why their future dominance was unforeseen. ${ }^{41}$ It was on this basis that from 1845 to 1852 Mill saw profit-sharing as the future and remained agnostic about cooperative production's success. Profit-sharing would serve to make 'the employers the real chiefs of the people, leading and guiding them in a work in which they also are interested-a work of cooperation, not of mere hiring and service; and justifying, by the superior capacity in which they contribute to the work, the higher remuneration which they receive for their share of it. ${ }^{42}$ By contrast, Mill in 1845 saw worker control as good both if it succeeded, and if (as implied) it failed, for it could 'prove to the operatives that the profits of the employer are but the necessary price paid for the superiority of management produced 
by the stimulus of individual interest; and that if the capitalist be the costliest part of the machinery of production, he more than repays his cost. ${ }^{143}$ In 1848 and 1849 Mill argued against cooperative production's plausibility, associating all necessary leadership with the capitalist, equating those whose work was most necessary and who deserved a greater interest in the success of the concern with those who provided funds and needed incentives to do so, through higher rewards and a greater voice. ${ }^{44}$ Mill's 1850 evidence to the Select Committee on the Savings of the Middle and Working Classes shows that whilst he saw it as possible that profits were inflated by the wealthy having an uncompetitive monopoly on the capital needed to set up in business, he was genuinely uncertain about the economic viability of cooperative production. ${ }^{45}$ Mill desired, like Carlyle, that 'the rule that they who do not work shall not eat, will be applied not to paupers only, but impartially to all'. ${ }^{46}$ Yet just as Carlyle had been clear that the leaders of industry were a species of workers, Mill too saw it as at least possible that the capitalist was engaged in irreplaceable labour as well as the provision of funds for the carrying on of large enterprises. ${ }^{47}$

By 1852 Mill's outlook had changed and profit-sharing had become a mere waystation before cooperative production. ${ }^{48}$ Given Mill's moral support for cooperative production in 1845 this must be seen far less as a normative shift than the resolution of what was for Mill a factual question, allowing a more ambitious statement of how far the movement towards partnership would travel. ${ }^{49}$ The expansion meant that Mill could now effectively describe the natural evolution of private property under economic competition as resulting in the collective ownership of the means of production. The novel part of Mill's argument was that the capitalist's particular contribution could be seen to be dispensable because some workers had shown in practice the capacities of saving and collective management to make it so. Mill believed that he had garnered such evidence by 1852 from Henri Feugueray's accounts of non-state-owned French 
cooperative workshops. It is plain from the construction of the 'Probable futurity', which ballooned with examples of successful businesses and even statements of their accounts over the course of its variants, that although cooperative production meshed with workers' independence, Mill would not have launched into predictions of the success of a mode of economic organization without having any evidence of such success. As he put it, 'If only a few operatives had attempted this arduous task, or if, while many attempted it, a few only had succeeded, their success might have been deemed to furnish no argument for their system as a permanent mode of industrial organization. ${ }^{50}$ This statement would come to seem less watertight over the next forty years as a large number of cooperative experiments in Britain did in fact fail to gain permanent footholds. As with all of Mill's reasoning here and on socialism in general, the ultimate question was one of trial and observation. The observation having been made, however, to Mill's mind the absence of cooperation's proliferation could be seen as a mark of the moral failings of workers. ${ }^{51}$ As Mill wrote in 1864 , 'as long as there are any working people who are dishonest—as long as there are any who are idle, who are intemperate, who are spendthrifts—so long there will be working people who are only fit to be receivers of wages. ${ }^{12}$ Mill's predictions thus helped to create an atmosphere among advanced liberals in which it was unclear whether to theorize the economic difficulty of cooperative production, or whether to simply engage in further moral exhortation.

In 1865 Mill's chapter showed signs of reversion. The crucial sentence outlining the chapter's predictions now ceased to refer to profit-sharing as temporary, and made cooperative production's ultimate success less certain. ${ }^{53}$ This change was accompanied by a statement that profit-sharing schemes might be desirable for 'a considerable length of time', since they preserved unity of authority for effective decision-making, and 'the competition of capable persons who in the event of failure are to have all the loss and in the case of success the greater part of the gain'. ${ }^{54}$ The problem of how to move from 
profit-sharing to cooperative production thus re-emerged and was still present at the end of Mill's life as he wrote the Chapters on Socialism, and hymned profit-sharing's successes whilst seeing its supersession by worker ownership as dependent on employers voluntarily bequeathing businesses to their employees. ${ }^{55}$ These changes have in some recent accounts been ignored as authors traced Mill's steady one-way journey towards cooperative and socialist commitments. ${ }^{56}$ What they reveal is significant however, as Mill's commitment to cooperative production began to cleave away from his commitment to the competitive workings of the market which would safeguard active character. Mill's joining of the cultural authority of political economy to the idea of replacing private individual ownership of collective endeavours began to fracture. These changes also show Mill as affected by his surroundings, in ways that remind us that Millian political economy was a body of knowledge with rules not determined in a simple sense by Mill's moral values.

One reason for the changes is that much of what mattered to Mill about cooperation was just as easily achievable with profit-sharing. The aims of making workers in some sense partners, of making them exert themselves for a common goal, and above all of achieving proportionate reward, so that workers and the capitalist would be paid at the rate appropriate to their contributions to the enterprise, were all potentially achieved by profit-sharing. It served sufficiently to create an associational industrial virtue. Too much has been made of Mill's statement that cooperation would embody the 'best aspirations of the democratic spirit. ${ }^{57}$ This did not indicate simply a desire to extend democracy to economic institutions, but was (as the next clause indicates) a reference to ending the distinction of the 'industrious and the idle'. ${ }^{58}$ Idleness (and selfishness) were embodied in workers who would rather work for the equal reward of wages than stake their remuneration on the success of a collective undertaking. ${ }^{59}$ The capitalist, however, 
might very well be industrious, and this was precisely what Mill's uncertainty over cooperative production indicated.

Another important reason for the change was that profit-sharing was now in fact being carried out. The 1860s saw a new general enthusiasm for profit-sharing, consisting of several schemes and a great deal of publicity, and resulting in the spread of the language of 'industrial partnership'. The most famous of these was that of the Yorkshire coal-mining firm of Henry Briggs, Son, and Company, proposed in 1864. The Briggs family contacted George Jacob Holyoake, who engaged in a publicity exercise on their behalf, sending the prospectus to Mill, Fawcett, and Louis Blanc. ${ }^{60}$ Mill wrote back that the Briggs family had 'done themselves great honour in being the originators in England of one of the two modes of Co-operation which are probably destined to divide the field of employment between them. ${ }^{61}$ When Mill reasserted his doubts about the success of cooperative production, he was in part reflecting the fact that his original vision of profit-sharing now appeared to be coming to fruition, and had captured the attention of the country at large.

This general enthusiasm was accompanied by changes to the law. As Mill had pointed out, the law that all who shared in profits be treated as partners with unlimited liability made incredibly difficult a scheme like that of the Parisian house-painting firm Maison Leclaire that had been publicized by the ex-Saint-Simonian Charles Duveyrier and thence through Mill's own writings. ${ }^{62}$ By the 1852 edition of the Principles which had privileged cooperative production, Mill had been aware that the recent Industrial and Provident Societies Act had given new legal protection to producers' cooperatives whilst leaving difficulties with profit-sharing untouched. ${ }^{63}$ Such difficulties were removed by an Act to Amend the Law of Partnership in 1865, which nevertheless made it clear that profit-sharing did not render the 'servant or agent' a partner, or give them the rights of a partner. ${ }^{64}$ This is worth noting not least because it made it clear that profit-sharing was 
not in legal terms what Mill's rhetoric had suggested that it could be: an end to hiring and service and a new form of partnership. ${ }^{65}$

Mill was also moving in tandem with sympathetic figures within political economy. In May of 1863 Henry Fawcett had proposed the question 'To what extent is the principle of Co-operative Trade Societies among the Working Classes economically sound?' at the Political Economy Club. Mill wrote to Fawcett after having missed the debate, making clear that cooperation depended on workers' morality, but also conceding that certain industries might be more difficult to collectively manage. ${ }^{66}$ Fawcett had made clear on a similar basis that cooperative production was not as certain of success as consumer cooperatives in his own extremely successful Manual of political economy, effectively a condensed version of Mill's Principles. ${ }^{67}$ William Thomas Thornton, who was likewise enamoured of cooperation's potential and convinced it had a bright future, had also written in 1864 of the advantages of unity of control, only outweighed by cooperation's sole advantage of worker incentivization, thus seeing a significant permanent role for profit-sharing. ${ }^{68}$ Mill, Fawcett, Thornton, and Cairnes shared a sense of a cooperative principle whose highest form was cooperative production. Yet the framework within which the economic rationale for cooperation had been couched logically led to the conclusion that profit-sharing firms would undersell those owned by workers. Economic concerns with the sources of firms' efficiency did not directly support Mill's historical account of the emergence of a society of equal and autonomous partners.

IV

These considerations matter in part because much of what the 'Probable futurity' effected in changing the tone of discussion of labour relations was due to the authority of political economy. The campaigner for cooperative production George Jacob Holyoake 
made this clear when he expressed his gratitude that 'it was Mr. John Stuart Mill who, as an authority in political economy, extended to co-operation scientific recognition'. ${ }^{69}$ Mill's text had a similar importance for the Christian Socialists and their own ideals of worker self-governance. When Charles Kingsley cited the predictive force of the 'Probable futurity' as part of a pairing with the moral lessons of the Bible in his novel Alton Locke, it was a mark of the way that he acknowledged the worth of political economy whilst seeking also to keep its claims within proper bounds. ${ }^{70}$ Frederick Denison Maurice invoked Mill as an economist to support the Christian Socialist agenda. ${ }^{71}$ John Malcolm Ludlow too employed the chapters on property from the second edition of the Principles by the 'great living master of political economy' to trump the criticisms of the essayist William Rathbone Greg and show the potential viability of socialist ideas. ${ }^{72}$ It was simply the culmination of this tendency when another of the group, Frederick Furnivall, asked Mill's permission to republish the 'Probable futurity' as a pamphlet for workers. ${ }^{73}$

Mill's economic authority also directly helped to cause profit-sharing and cooperative production to garner more serious discussion that it otherwise would have done from those who saw political economy as the primary means of discussing social issues. Yet his perspective clearly failed to carry all before it. Greg shared a sense of Mill's authority with his Christian Socialist opponents. ${ }^{74}$ He was a scion of a successful Lancashire mill-owning family of a classically paternalist bent, whose brother Samuel had been lauded in the 1840s for his experimental model employment practices but who had also left the family distraught by the end of the decade by almost bankrupting his branch of the firm. ${ }^{75}$ William wrote for the Edinburgh Review in the late 1840 s and early 1850 s to combat what he saw as the philanthropic economic illiteracy of both the Christian Socialists and Thornton Hunt's Leader, not least on a Malthusian basis Mill obviously shared. ${ }^{76}$ Greg was not interested in institutional change, however, so much as a more systematic and better-informed benevolence that would accept wage labour as part of a 
world divinely ordained to make the virtuous happy. ${ }^{77}$ He was sceptical as to even profitsharing succeeding, given that wages could be seen as simply a regular and secure form of granting workers their share in profits without exposing them to losses. ${ }^{78}$ This was not an effective argument against simply adding a bonus to wages, but did show an important concern with the stability of workers' pay that cooperative production would clearly jeopardize. On worker control, Greg in turn saw elected managers as likely to lack zeal, and the 'power to enforce subordination', and doubted that cooperators could appreciate their true interests or obtain such knowledge from a manager more cheaply than they already did. $^{79}$ Greg's real hopes unmistakably lay in economic growth and individual advancement.

The same lines of argument were taken up by John Ramsay McCulloch, who asserted that in the vast majority of cases giving workers a share in profits was impossible, since it would involve workers both sharing in losses, with high risk of penury, and having a partner's interest in control, limiting the effective authority of employers. ${ }^{80}$ John Lalor, whose work was primarily an attempt to reassert against Mill the Christian political economy of cyclical commercial convulsions put forward by Thomas Chalmers, nevertheless shared with Mill a sense of profit-sharing and both consumer and producer cooperatives as important phenomena. ${ }^{81}$ Yet he also cited with approval one of the articles in which Greg had expressed scepticism over cooperative production, and was clear himself of the difficulties of workers understanding the preciousness of that 'industrial discipline which capital now enforces'. ${ }^{82}$ Charles Morrison's Essay on the relations between labour and capital involved an attempt to negotiate between the expert authority of Mill on the one hand, and Greg and McCulloch on the other. ${ }^{83}$ The latter won out, with Morrison seeing prospects for profit-sharing as highly limited, and cooperative production as facing nigh-on insuperable difficulties, although Morrison could agree (as had Lalor and Greg) with Mill's earlier sentiments that failure on any of these fronts 
would teach workers a lesson in the value of capitalist management and hence social cohesion. ${ }^{84}$

If by the 1860s Mill had more support from other economic thinkers, his predictions were also opened up to a new front of disagreement from the arguments of the British Positivists, most notably Edward Beesly and Frederic Harrison. The broader context for this fault-line was evidently the difference between Millian liberalism and the ideals of Comte, yet its imminent force came from heightened discussion of trade unions, representing a new challenge to a vision of workplace harmony. This shift was signalled by the National Association for the Promotion of Social Science's report on Trades' societies and strikes in 1860. The report emphasized that strikes were capable of raising wages, and presented unions as established institutions which were necessary in order to create a genuine parity between buyers and sellers of labour. The idea that unions helped to achieve a fair market price helped to end a crude version of the wages fund doctrine, overturning the harsh anti-union line taken by figures like Nassau Senior and Harriet Martineau. ${ }^{85}$ Yet if the report united a new wave of opinion including Positivists, Christian Socialists, and Millian political economy in condemnation of rigid ideas of wage determination, it could not create unity as to the future. The report did not entirely condone trade union activity, yet there was no single obvious alternative. ${ }^{86}$ The majority report mentioned the beneficial effects of worker investment in joint-stock companies, and the minority report the formation of national councils of capitalists and workmen. ${ }^{87}$ In this context, Henry Fawcett effectively rewrote the 'Probable futurity', incorporating trade unions into its framework. In his 1860 article on strikes which represents his most important contribution to political economy, Fawcett argued that it would be possible for workers to temporarily raise wages by means of a strike during a period of extraordinary profits, and before the ordinary rate of profit had had time to assert itself by attracting more competitors to an industry. In these circumstances it 
would also be rational for employers to capitulate, and the negotiation so effected was for Fawcett effectively the creation of a profit-sharing scheme. Unions could be seen as a rational form of association appearing once feudalism and philanthropy had been thrown off, demonstrating the rise of independence. They could also be shown to lead towards cooperative production. 'Intelligence induces combinations, combination tends to create a partnership between employers and employed, and this will lead to those higher forms of co-operation which will alike realize all that has been sought either by the economist or the philanthropist. ${ }^{88}$ Fawcett sought to make the NAPSS conclusions safe for political economy and liberal class harmony by stressing that unions could achieve no more than profit-sharing, and were its logical precursors. On this basis Mill could incorporate Fawcett's recognition of bargaining over the price of labour into the Principles. ${ }^{89}$ It also made easier Mill's abandonment of the wages fund doctrine that saw wages as determined by a set proportion of capital divided amongst labourers, since Mill shared with Thornton, who pressed this issue to conclusion, a sense of unions paving the way for profit-sharing and cooperatives..$^{90}$

This opening up of such issues also afforded an opportunity for Positivism, however. Over the course of the 1860s Frederic Harrison and Edward Beesly campaigned to afford trade unions greater legal recognition, and in the process also sought to make clear that this was not part of the rise of workers' independence, but rather a movement towards the instating of correct moral leadership in industry. Following Mill's Auguste Comte and positivism, in 1866 Harrison hit back at the cooperative ideal, describing the cooperative movement in terms that made it seem either irrelevant to the question of the employment relationship, motivated by selfishness, or in fact Positivism in disguise. Not only was cooperation's success limited to retail, but cooperators themselves were divided between one party motivated 'to keep themselves with their own money' and another who wanted a system in which 'capital freely devotes 
part of its profit to labour..$^{91}$ Harrison denied the plausibility of Mill's moral vision of intertwined economic competence and virtuous independence, in mutually supportive growth towards a new sociability of equals. Harrison had a deep admiration for Carlyle, who he saw as in many ways teaching the same lessons as Comte. ${ }^{92}$ The association can be seen in Harrison's assertion that 'The head of a great production is like the captain of a ship or the general of an army. He must have scientific knowledge, technical knowledge, practical knowledge, presence of mind, dash, courage, zeal, and the habit of command.' Such a head required the total freedom also afforded by ownership, for 'You cannot buy the inspiring authority any more than the electric will of a great military or political chief. It is impossible to bire commercial genius and the instincts of a skilful trader.' For Harrison 'The main and the just complaint of labour' was the 'oppressive use' of the power of the capitalist. Thus, a 'great, free, and wise capitalist' should 'by advice, help, example, and experience, promote the welfare of those about him', acting 'almost as a providence on earth', a possibility presaged by the spirit in which 'some of the largest estates' and 'some very large manufactories' were already carried on. The lauding of existing business enterprises as models of moralization veered closer to Carlyle than to Comte's positive polity, and the tone was reinforced with a reference to the need to limit 'The Gospel according to Mammon'. ${ }^{93}$

The same basic points were made by Edward Beesly in his lecture on the 'Social future of the working classes' delivered to an audience of trade unionists in May 1868, with trade unionism marking an attempt to gain security and a moralized workplace in which power would be exercised more in accordance with popular consent, and above all for stability of remuneration. Industrial organization required the same 'great power and great responsibility' as military organization. The point threw into stark relief the impracticability of cooperative production: 'Special skill and training, unity of purpose, promptitude, and, occasionally, even secrecy, are necessary for a successful direction of 
industry just as much as of war. ${ }^{, 94}$ Beesly came close to self-contradiction in claiming both that cooperation required a disinterestedness only possible through organized religion, and also appealed to 'sharp, shifty men' interested in a business success that was little to do with morality. ${ }^{95}$ This was, however, a continuation of the attempt to claim that what was good in cooperation was a plea for the moral regeneration of hierarchy in industry, and that the rest of its ideals were a backward selfishness.

The Positivist vision was not laughed off by the workers and union leaders such as Robert Applegarth and George Odger to whom it was addressed. ${ }^{96}$ Beesly's attack on cooperation was also capable of appreciation by those who did not sympathize with ultimate Positivist aims. ${ }^{97}$ The strength of the Positivist attack, coupled with their influence as legal campaigners, can be seen in the need felt by both Thornton and Cairnes to respond with defenses of Mill's ideals. In On labour Thornton attacked Harrison's interpretation of unionism's meaning, and ridiculed his marriage of 'Captains of Industry' to a defense of unionism: “Captains of Industry,' quotha. Yes, verily, every unionist private may perhaps be well enough content that there should be officers in the army of labour; only with this important proviso, that he himself should hold one of the commissions. ${ }^{, 98}$ Cairnes presented cooperative production in his Leading principles of 1874 as a direct refutation of the Positivists. ${ }^{99}$ This went hand in hand with his clashes over method in social science with Harrison in the mid-1870s, in which he also criticized Comte's law of three stages, and cast doubt on any existing capacity to predict specific events rather than to cautiously extrapolate tendencies that might be counter-acted. ${ }^{100}$ Beesly and Harrison's implacable opposition to the moral ideals of cooperative production dealt it a significant blow. They contributed to shifting the terms of debate from a language of independence versus dependence within which Mill had operated, to a more recognisably twentieth-century language of individualism versus collectivism within which Mill's particular vision of decentred public virtue was harder both to place 
and to appreciate. Equally, they helped to keep to the fore questions of talent and leadership that challenged cooperation's plausibility.

\section{$\mathrm{V}$}

Such criticisms were to gain in force. In his 1888 History of political economy the Positivist John Kells Ingram took the opportunity to point out one of the ways in which the work of John Stuart Mill and John Elliott Cairnes had been superseded. Their neglect of the 'function of the entrepreneur' had reduced this vital figure to little more than the owner of capital, a trend partially corrected by Walter Bagehot, Francis Amasa Walker, and Alfred Marshall. For Ingram thinking about business leadership had been partly intentionally retarded: 'It can scarcely be doubted that a foregone conclusion in favour of the system of (so-called) cooperation has sometimes led economists to keep these important considerations in the background. ${ }^{101}$ Despite evident bias, Ingram was right that Mill's vision of cooperative production and its union of capital and labour was in many ways lent the death-blow within economics by the formalization of ideas regarding the primacy of scarce talent for business success, codified in the concept of the entrepreneur.

Marshall's presence in Ingram's list is most revealing, since he had maintained strong hopes for cooperative production. In 1873, in a paper presented to the Cambridge Reform Club, Marshall had made clear that in an ideal economy with highly educated workers, 'in many industries production would be mainly carried on, as Mr and Mrs Mill have prophesied, by "the association of labourers among themselves on terms of equality, collectively owning the capital with which they carry on their operations, and working under managers elected and removable by themselves." ${ }^{\prime 102}$ In the early 1920s, Marshall added a note to the manuscript of 'The future of the working classes', stating that 'it bears the marks of the over-sanguine temperament of youth., ${ }^{103}$ 
Marshall's changing opinions were in part influenced by the work of others. $\mathrm{He}$ saw the difficulties of cooperators recognizing the value of management well-outlined in an 1874 article by Thomas Brassey, son of the famous profit-sharing railway contractor of the same name.. ${ }^{104}$ Here, as in Brassey's Work and wages of 1872, cooperative production was supported, but Brassey also drew on experience to discuss the important market value of leadership which made cooperative production so hard, particularly in complex enterprises. ${ }^{105}$ Harrison had in fact used Brassey's evidence of business leadership's importance to look forward to when 'co-operation, and every other bastard form of socialism, will be forgotten as the clumsy efforts of a generation which had failed to understand even the problem that was set for it to solve'. ${ }^{106}$ Marshall's Economics of industry of 1879 cited Brassey's Lectures on the labour question, at the point at which Marshall outlined a difference between the decision-making or 'engineering' of a business, and its more routine 'superintendence', making clear that cooperation would be harder where engineering was more significant. ${ }^{107}$ Marshall likewise discussed Walter Bagehot whilst outlining the concept of 'business power' as a requisite for production, which had its own market value separate from that of either capital or skilled labour, and crucially involved a set of relatively non-specialized organizational skills learnt through practice. ${ }^{108}$ Walker's Wages question was also used by Marshall to argue that 'It is no longer true that a man becomes an employer because he is a capitalist. Men command capital because they have the qualifications to profitably employ labour. To these captains of industry or organizers of industry capital and labour alike resort for the opportunity to perform their several functions. ${ }^{109}$

These points served to undermine the Millian conception of the 'wages of superintendence' as the element of profit the capitalist earned from exertion rather than investment, and thus to distinguish routine labour from entrepreneurship. Walker in particular saw the cooperation of Mill and Cairnes as entirely misconceived thanks to its 
lack of appreciation for the primacy of leadership to profitability, an argument supported with the writings of Harrison. ${ }^{110}$ Marshall still differed significantly from Walker, who despite having provided the 'most graphic' depiction of the entrepreneur, regarded business talent too much as a natural resource and not enough as created by training and education. ${ }^{111}$ Such education clearly left Marshall some opening for cooperation, but the theorization of business leadership as a distinct occupation with specific skills was not easily reconciled with worker self-government. Presiding at the Cooperative Congress at Ipswich in 1889, Marshall stressed that cooperative production was not labour hiring capital, but the harder proposition of workers' business ability attracting capital. His speech was effectively a plea for the consumer Cooperative Wholesale to continue to support cooperative production from without, despite the latter's familiar litany of failures. ${ }^{112}$

When Marshall's Principles of economics appeared in 1890, it had the entrepreneur at its core. For Marshall the modern economic world was one with the 'growth of business UNDERTAKERS' and manufacturing simply increased the scope for 'the natural selection of the fittest to undertake, to organize, and to manage'. It was no longer the case as in early and mid-nineteenth century accounts that employment was due to the need for capitalists to provide (increasingly large and costly) tools to workers; rather it was the division between generalized business ability and labour that represented 'the chief fact in the form of modern civilization, the kernel of the modern economic problem. ${ }^{113}$ In this 1890 edition Marshall still put a brave face on cooperative production's possible future success, writing that its difficulties would be reduced through experience and education, although also by the federation of cooperatives (again indicating the need for stores to subsidize workshops). A series of changes between the first and second edition, however, indicate Marshall hardening in a view that cooperative production could not compete successfully in a world where scarce business ability so 
strongly determined efficiency. ${ }^{114}$ These changes were possibly due to disillusionment with the Cooperative Wholesale drifting away from cooperative production, particularly under the influence of Benjamin Jones, who spoke after Marshall at Ipswich in 1889, and who influenced Beatrice Potter to regard the consumer movement as a complement to state socialism. ${ }^{115}$ They were also a tipping point in a much longer argument about the plausible social future.

To return to our starting point, when L. L. Price, a friend of Marshall's, wrote of the 'Probable futurity' in 1892, he came not to praise cooperative production but to bury it. Price was reviewing Beatrice Potter's History of co-operation which of course had the same intention, though Price was not straightforwardly allying with Potter's partisan but since rather influential account of cooperative production and profit-sharing as an individualistic, profit-driven deviation from the views of Robert Owen. Nevertheless Price regarded Mill's cooperation as founded on confusions surrounding managerial remuneration and wages, as well as profit and interest, dating back to Adam Smith. In addition cooperation was morally questionable given the desirability of stable incomes for workers. Mill's chapter also had only a 'specious appearance of being 'in conformity with nature"' in its linear predictions, for 'she rather allows scope for many different experiments in many different directions', a statement that reminds us that despite Mill's frequently experimental rhetoric, in this instance his force had come from more direct prediction. $^{116}$

The support of economic thought for cooperative production had been conflicted, and embattled, and was now to a large extent over. It had emerged not only from Mill's normative concerns, but from an attempt to wed a social scientific account of the rise of workers' independence with the authority of political economy. This marriage 
was in turn made plausible by the nature of the era's economic thought, in which the capitalist subsumed concepts of both investment and management, with capital provision tending to overshadow talent as a means of understanding employment hierarchies. Compounding this was an absorption of questions of talent within a discourse of general education and improvement of character (rather than occupational training), which resulted in a certain moralizing vagueness about how cooperation might be achieved. By the 1890s, while there were still various possibilities for lessening wage disputes, most notably through arbitration, there was now no longer any sense for liberal economists that the employment relationship itself represented a soluble problem, although at times it clearly remained a problem. Under Marshall, there was now a fairly clear divide between questions of economic analysis and the success of types of firm, and those of the potentialities of a new stage of social development. Moreover, images of the rare competencies of the entrepreneur in organizing others were to make it hard to rediscover Mill's vision of the market itself as a buttress for a universally independent civic personality.

Dr. Jocelyn Paul Betts, Corpus Christi College, Cambridge, CB2 1RH

* I wish to thank the journal's two anonymous reviewers, and Michael Ledger-Lomas and Duncan Kelly for comments on a draft of this article.

${ }^{1}$ John Stuart Mill, The collected works of John Stuart Mill, ed. John M. Robson (33 vols., Toronto and London, 1963-91), (hereafter CW), I, 255.

${ }^{2}$ N. B. de Marchi, 'The success of Mill's Principles', History of Political Economy 6, (1974), 119-157, 138, 150.

${ }^{3}$ See eg. John Elliott Cairnes, 'His work in political economy', in John Stuart Mill: his life and works, (Boston, 1873), pp. 65-73, p. 70; Cairnes, 'Co-operation in the slate quarries 
of north Wales', Macmillan's Magazine, 11 (Jan., 1865), 181-90; Henry Fawcett, Manual of political economy (Cambridge and London, 1863), pp. 276-93; William Thomas Thornton, On labour (London, 1869), pp. 341-439; Alfred Marshall, 'The future of the working classes', in A. C. Pigou, ed., Memorials of Alfred Marshall (London, 1925), pp. 101-18.

${ }^{4}$ L. L. Price, 'Profit-sharing and cooperative production', The Economic Journal 2 (Sep., 1892), 442-62, 444-5.

${ }^{5}$ Beatrice Webb, My apprenticeship (Cambridge, 1979), p. 363.

${ }^{6}$ Eugenio Biagini, Liberty, retrenchment, and reform (Cambridge, 1992), p. 143.

${ }^{7}$ Recent discussions involving interpretation of the 'Probable futurity' include: Richard Ashcraft, 'John Stuart Mill and the theoretical foundations of democratic socialism', in Eldon J. Eisenach, ed., Mill and the moral character of liberalism (University Park, Pennsylvania, 1998), pp. 169-89; Bruce Baum, 'J. S. Mill and liberal socialism', in Nadia Urbinati and Alex Zakaras, eds., J. S. Mill's political thought (Cambridge, 2007), pp. 98-123; Nicholas Capaldi, John Stuart Mill (Cambridge, 2004), pp. 201-24; Gregory Claeys, 'Justice, independence, and industrial democracy: the development of John Stuart Mill's views on socialism', The Journal of Politics, 49 (Feb., 1987), 122-147; Claeys, Mill and paternalism (Cambridge, 2013), chapter two; Samuel Hollander, The economics of John Stuart Mill, 2 vols., (Oxford, 1985), II, chapter ten; Oskar Kurer, John Stuart Mill: the politics of progress (London, 1991), chapter two; Kurer, 'J.S. Mill and Utopian Socialism', Economic Record, 68 (1992), 222-32; John Medearis, 'Labor, democracy, utility and Mill's critique of private property', American Journal of Political Science, 49 (2005), 135-49;_Dale E. Miller, 'Mill's 'Socialism", Politics, Philosophy and Economics 2, (June, 2003), 213-38; Richard Reeves, Jobn Stuart Mill (London, 2007), chapter nine; Jonathan Riley, 'J.S. Mill's liberal utilitarian assessment of capitalism versus socialism', Utilitas 8, (1996) 39-71; Frederick Rosen, Mill (Oxford, 2013), pp. 151-79; Wendy Sarvasy, 'A reconsideration of the 
development and structure of John Stuart Mill's socialism', Western Political Quarterly 38, (1985), 312-33; William Stafford, 'How can a paradigmatic liberal call himself a socialist? The case of John Stuart Mill', Journal of Political Ideologies 3, (1998), 325-45; C. L. Ten 'Democracy, socialism, and the working classes' in John Skorupski, ed., The Cambridge companion to Mill (Cambridge, 1998), pp. 372-95; Donald Winch, Wealth and life (Cambridge, 2009), chapter two.

${ }^{8}$ This concern is overt in Baum, 'J.S. Mill and liberal socialism'; Capaldi, John Stuart Mill, pp. 201-24; Claeys, 'Justice, independence and industrial democracy; Claeys, Mill and paternalism, chapter two; Miller, 'Mill's 'socialism"; Sarvasy, 'A reconsideration of the development and structure of John Stuart Mill's socialism'; Stafford, 'How can a paradigmatic liberal call himself a socialist?'.

${ }^{9}$ The summary discussion in Claeys, Mill and paternalism, 166-72 provides a useful level of nuance on Mill's ideals that helps to further the transcendence of discussion of 'capitalism' versus 'socialism' as regards Mill. In effectively stressing Mill's normative coherence, however, the difference of profit-sharing from cooperative production is potentially underplayed, (specifically at 154-5 and 167-8), and broader tensions seen when examining Mill's context and predictive force are obscured.

${ }^{10}$ Mill, $C W, \mathrm{I}, 171-3$.

${ }^{11}$ Ibid., IV, 369.

${ }^{12}$ Though this was a strong reason Mill took to Carlyle, and vice versa. Mill, $C W$, XII, 85-6.

${ }^{13}$ Which Mill strongly supported. See Mill, $C W$, XIII, 414.

${ }^{14}$ John Stuart Mill and Auguste Comte, The correspondence of John Stuart Mill and Auguste

Comte, ed. Oscar A. Haac, trans. Oscar A. Haac (New Brunswick, 1995), p. 109.

${ }^{15}$ Mill, CW, XVIII, 119-36. 
${ }^{16}$ See Auguste Comte, Cours de philosophie positive, (6 vols., Paris, 1830-1842), VI, 571-6.

${ }^{17}$ Mill, $C W, \mathrm{X}, 341$. The jarring of this statement with 'textbook' Victorian individualism has been taken up in Stefan Collini, Public moralists (Oxford, 1993), p. 71.

${ }^{18}$ See eg. Thomas Carlyle, The works of Thomas Carlyle, ed. Henry Duff Traill, (30 vols., London, 1896-9), X, 209, 270-6.

${ }^{19}$ Mill, $C W$, I, 241.

${ }^{20}$ See John Ruskin, The complete works of John Ruskin, eds. E. T. Cook and Alexander Wedderburn (39 vols., London, 1903-1912), XVII, 31-3, XXIX, 146-8. Ruskin's relationship with Mill has been well-described in Winch, Wealth and life, chapter three.

${ }^{21}$ On relations between Comte and the Saint-Simonians see Mary Pickering, 'Auguste Comte and the Saint-Simonians', Journal of French Historical Studies, 18 (Spring, 1993), 21136.

${ }^{22}$ See Keith Michael Baker, 'Closing the French Revolution: Saint-Simon and Comte', in François Furet and Mona Ozouf, eds., The transformation of political culture 1789-1848 (Oxford, 1989), pp. 323-39.

${ }^{23}$ Mary Pickering, Auguste Comte (3 vols., Cambridge, 1993-2009), I, 92-9, 109-12.

${ }^{24}$ Comte, Cours, IV, 264-77.

${ }^{25}$ See Auguste Comte, Early political writings, ed. H. S. Jones, trans. H. S. Jones, (Cambridge, 1998), pp. 204-11.

${ }^{26}$ See especially Mill, CW, III, 942-4.

${ }^{27}$ See Arthur Helps, The claims of labour (London, 1844), pp. 33-4.

${ }^{28}$ Mill, $C W$, IV, 375.

${ }^{29}$ A general connection between the message of this review, its opposition to Carlyle, and the 'Probable futurity' has been established in Winch, Wealth and life, chapter two, especially p. 50. As Winch notes here this 1845 argument helps to show the limited 
usefulness of any argument as to Harriet Taylor's later responsibility for the intellectual content of the 'Probable futurity', despite her suggestion as to its inclusion in the

\section{Principles.}

${ }^{30}$ See Bruce L. Kinzer, England's disgrace? (Toronto, 2001), chapter two.

${ }^{31}$ Mill and Comte, Correspondence, pp. 382-4.

${ }^{32}$ As suggested by Adelaide Weinberg, The influence of Auguste Comte on the economics of John Stuart Mill (London, 1982), pp. 373-83.

${ }^{33}$ Comte, Early political writings, p. 223; Carlyle, Works, XXVIII, 271-2.

${ }^{34}$ The kind of reading offered in eg. Capaldi, John Stuart Mill, pp. 203-4; Rosen, Mill, pp. $171-4$.

${ }^{35}$ One should note that the first (1843) edition of Mill's Logic remained agnostic about Comte's predictions. The second (1846) edition was overtly critical. Mill, CW, VIII, 925.

${ }^{36}$ Mill, $C W, \mathrm{X}, 325$.

${ }^{37}$ Ibid., X, 325, XVIII, 50-2.

${ }^{38}$ Ibid., III, 761-4.

${ }^{39}$ As stressed in eg. Miller, 'Mill's 'Socialism', 221-3, Reeves, Mill, p. 224.

${ }^{40}$ Mill, CW, III, 766-7.

${ }^{41}$ Ibid., II, 137-40.

${ }^{42}$ Ibid., IV, 382.

${ }^{43}$ Ibid., 385.

${ }^{44}$ Ibid., III, 1013.

${ }^{45}$ Ibid., V, 411-2, 417-8.

${ }^{46}$ Ibid., I, 238.

${ }^{47}$ See eg. Carlyle, Works, X, 207-8. 
${ }^{48}$ Some examinations of Mill's cooperation treat it without any acknowledgement of such chronology, including Baum, 'J. S. Mill and liberal socialism'; Miller, 'Mill's 'Socialism"; Riley, 'J. S. Mill's liberal utilitarian assessment of capitalism versus socialism'.

${ }^{49}$ A point that tempers the suggested normative impact of events in 1848 in France in Claeys, Mill and paternalism, pp. 140-3; Capaldi, Mill, pp. 220-2. The impact of 1848, the influence of Harriet Taylor, and Mill's study of socialist authors at this time, can all be plausibly invoked as aiding the changing descriptions of Owenism, Fourierism, and SaintSimonianism in chapters one and two of book two of the Principles. Yet the basis on which Mill made cooperative production more plausible was distinct, as outlined above.

${ }^{50}$ Mill, CW, III, 776.

${ }^{51}$ Ibid., III, 793, XIV, 94-6, XV 545-6.

${ }^{52}$ Ibid., XXVIII, 7.

${ }^{53}$ Ibid., III, 769.

${ }^{54}$ Ibid., $792-3$.

${ }^{55}$ Ibid., V, 743.

${ }^{56}$ See Claeys, Mill and paternalism, pp. 154-5, where it is claimed that there is 'no evidence' that Mill retreated from an idea that profit-sharing 'would be supplanted' by 'collective ownership of capital'; Rosen, Mill. The changes have been noted as of some significance, though without context, in Kurer, 'J. S. Mill and utopian socialism'; Hollander, Economics of John Stuart Mill, II, 816-8.

${ }^{57}$ See Rosen, Mill, p. 178; Baum, 'J. S. Mill and liberal socialism', pp. 111-13.

${ }^{58}$ Mill, CW, IV, 793.

${ }^{59}$ Ibid., III, 783.

${ }^{60}$ George Jacob Holyoake, The history of co-operation (London, 1908), p. 446.

${ }^{61}$ Mill, $C W, \mathrm{XV}, 966-7$. 
${ }^{62}$ Ibid., 903.

${ }^{63}$ See Ibid., 904. The importance Mill accorded the change is evident in $C W, \mathrm{XIV}, 94-5$.

${ }^{64}$ See John Malcolm Ludlow and Lloyd Jones, The progress of the working class (London, 1867), p. 52.

${ }^{65}$ In addition the fairly rapid failure of the Briggs scheme and others by the 1870 s would in turn be widely discouraging to liberal observers, and tended to make discussion of profit-sharing itself (like cooperative production) more of a question of worker's morality than the efficiency provided by incentivization. See in particular Sedley Taylor, Profitsharing between capital and labour: six essays (London, 1884), preface.

${ }^{66}$ Ibid., 859.

${ }^{67}$ Henry Fawcett, Manual of political economy (London, 1863), pp. 284-93.

${ }^{68}$ William Thornton, 'Strikes and industrial co-operation', Westminster Review, 25 (Apr., 1864), 349-83, 368-9, 379-80.

${ }^{69}$ George Jacob Holyoake, John Stuart Mill as some of the working classes knew him (London, 1873), p. 3.

${ }^{70}$ Charles Kingsley, Alton Locke (Oxford, 1983), p. 301; See also Charles Kingsley, Novels, letters, and poems of Charles Kingsley, ed. Frances Kingsley (14 vols., London and New York, 1899), II, 75-6.

${ }^{71}$ Frederick Denison Maurice, Reasons for co-operation (London, 1851), p. 22.

${ }^{72}$ John Malcolm Ludlow, Christian socialism and its opponents (London, 1851), pp. 62-3.

${ }^{73}$ Mill, $C W, \mathrm{XIV}, 157$. Though the project did not come to fruition it led to certain edits including a harder line on workers who resisted proportionate pay.

${ }^{74}$ William Rathbone Greg, Essays on political and social science (2 vols., London, 1853), I, 382-6, 435-6, 451, 483. 
${ }^{75}$ Mary B. Rose, The Gregs of Quarry Bank. Mill (Cambridge, 1986), pp. 120-2; Jenny

Uglow, Eliqabeth Gaskell (London, 1999), p. 300.

${ }^{76}$ See eg. Greg, Essays, I, 481.

${ }^{77}$ Ibid., 460.

${ }^{78}$ Ibid., 377-86

${ }^{79}$ Ibid., 433.

${ }^{80}$ John Ramsay McCulloch, $A$ treatise on the circumstances which determine the rate of wages, (2nd edn., London, 1854), pp. 72-4.

${ }^{81}$ John Lalor, Money and morals (London, 1852), preface, p. 205. The Christian political economy of Chalmers is best treated in Boyd Hilton, Age of atonement (Oxford, 1986).

${ }^{82}$ Lalor, Money and morals, pp. 199-205.

${ }^{83}$ Charles Morrison, Essay on the relations between labour and capital (London, 1854), pp. viiviii, 111-47.

${ }^{84}$ Ibid., pp. $133-5$.

${ }^{85}$ See Mark C. Curthoys, Governments, labour, and the law in mid-Victorian Britain (Oxford, 2004), pp. 51-2; Mark Curthoys, “Secret organisation of trades': Harriet Martineau and 'free labour' in Victorian Britain', in Ella Dzelzainis and Cora Kaplan, eds., Harriet Martineau: authorship, society, and empire (Manchester, 2010), pp. 133-50, pp. 140-6.

${ }^{86}$ Lawrence Goldman, Science, reform, and politics in Victorian Britain: the social science association 1857-1886 (Cambridge, 2002), pp. 210-13.

${ }^{87}$ See 'Report', in Trades' societies and strikes (London, 1860), pp. v-xxi, pp. xvii-xxi.

${ }^{88}$ Henry Fawcett, 'Strikes: their tendencies and remedies', Westminster Review, 18 (July, 1860), 1-23, 23.

${ }^{89}$ Mill, CW, III, 932-3.

${ }^{90}$ Ibid., V, 666-7. 
${ }^{91}$ Frederic Harrison, 'Industrial co-operation', Fortnightly Review, 3 (Jan., 1866), 477-503, 485.

${ }^{92}$ See Frederic Harrison, Order and progress (London, 1875), pp. 31-43.

${ }^{93}$ Ibid., 491-503.

${ }^{94}$ Edward Spencer Beesly, 'The social future of the working class', Fortnightly Review, 5 (Mar., 1869), 344-63, 350-1.

${ }^{95}$ Ibid., 349-50, 354.

${ }^{96}$ Royden Harrison, 'Professor Beesly and the working-class movement', in Asa Briggs and John Saville, eds., Essays in labour history (London, 1960), pp. 205-41, p. 210.

${ }^{97}$ Anon., 'The future of the working-classes', Saturday Review of Politics, Literature, Science and Art, 27 (Mar. 13, 1869), 343-4.

${ }^{98}$ Thornton, On labour, pp. 165-72, 166.

${ }^{99}$ J. E. Cairnes, Some leading principles of political economy newly expounded (New York, 1874), pp. 283-91.

${ }^{100}$ J. E. Cairnes, 'M. Comte and political economy', Fortnightly Review, 7 (May., 1870), 579_ $602,601-2$.

${ }^{101}$ John Kells Ingram, A history of political economy (Edinburgh and New York, 1888), p. 227.

${ }^{102}$ Marshall, 'The future of the working classes', pp. 113-14.

${ }^{103}$ Ibid., p. 101.

${ }^{104}$ Alfred Marshall, The correspondence of Alfred Marshall, ed. John K. Whitaker (3 vols., Cambridge, 1996), I, 30.

105 Thomas Brassey, Work and wages (London, 1872), p. 260; Thomas Brassey, 'Cooperative production', Contemporary Review, 24 (July, 1874), 212-33, 213-4, 228. 
${ }^{106}$ Frederic Harrison, 'Mr. Brassey on work and wages', Fortnightly Review, 12 (Sep., 1872), 268-86, 286.

${ }^{107}$ Alfred Marshall and Mary Paley Marshall, The economics of industry (London, 1879), p. 221.

${ }^{108}$ Ibid., p. 116.

${ }^{109}$ Ibid., pp. 117-18.

${ }^{110}$ Francis Amasa Walker, The wages question (New York, 1876), pp. 252-85, 272-3, 277.

${ }^{111}$ Alfred Marshall, 'The theory of business profits', The Quarterly Journal of Economics, 1 (Jul., 1887), 477-81.

${ }^{112}$ Alfred Marshall, 'Co-operation', in Pigou, ed., Memorials, pp. 227-55.

${ }^{113}$ Alfred Marshall, Principles of economics (London, 1890), pp. 37-8.

${ }^{114}$ cf. Marshall, Principles (1 ${ }^{\text {st }}$ edn., London, 1890), pp. 366-8 and Alfred Marshall, Principles ( $2^{\text {nd }}$ edn., London, 1891), p. 363; Marshall, Principles ( $1^{\text {st }}$ edn.), pp. 629-31 and Marshall, Principles (2 $2^{\text {nd }}$ edn.), pp. 634-6.

${ }^{115}$ Philip N. Backstrom, Christian socialism and co-operation in Victorian England (London, 1974), pp. 187-201.

${ }^{116}$ Price, 'Profit-sharing and cooperative production', 455. 